\title{
Maria-Ecclesia and the Meaning of Marriage in the Late 13th Century
}

\begin{abstract}
By the end of the thirteenth century, the Church of Rome defined human marriage as incomplete before consummation in virtuous carnal intercourse. This article focuses on Cimabue's emotionally charged and sexually explicit fresco representation of the Assumption of the Virgin, and shows that its stylistic verisimilitude makes visible human love as proof of the spiritual miracle of the Mystic Marriage of Christ and Maria-Ecclesia.
\end{abstract}

One of the greatest and most startling images of the Marriage of Christ and Church was painted by Cimabue in the polygonal apse of San Francesco in Assisi about 1280 (Fig. 1). It is so unusual from every point of view, stylistic, iconographic, theological, that it demands extensive analysis and explanation. Because of its condition, and a certain amount of expurgation, it was not, until very recently, explored in any detail. What I will present today is an expanded reprise of the observations about this fresco I first presented in the book my husband and I published together, first in Italian and then in English, in 1999 and 2001. ${ }^{1}$ In that work I showed that the image represents an incredibly direct and explicit depiction of the Mystic Marriage of Christ and Maria-Ecclesia. Here, I shall focus on the meaning of this marriage in the last quarter of the thirteenth century.

From a narrative point of view, the scene forms part of the Life of the Virgin in eight episodes, all of which come either before the birth or after the death of Christ. The cycle is arranged in what I have called "the Apse Pattern," that is it circles the apse from left to right in descending order, although it seems to skip on the top two tiers because of the intervening windows. ${ }^{2}$ Scenes from before Christ's birth move back and forth on two tiers on the solid side walls at the entrance to the apse. Scenes from after the Passion, which proceed around the lower tier, passing across the papal throne in the central facet, are four episodes of Mary's Last Days: Her Farewell to the Apostles, her funeral (Koimesis), Assumption, and Glorification. It is the Assumption that signals a truly climactic moment in the expression of Franciscan theology and, as we shall see, in the meaning of marriage as it relates to the theology of the time.

1. Lavin and Lavin, 1999 and 2001.

2. Lavin 1994, Chap. 1. 


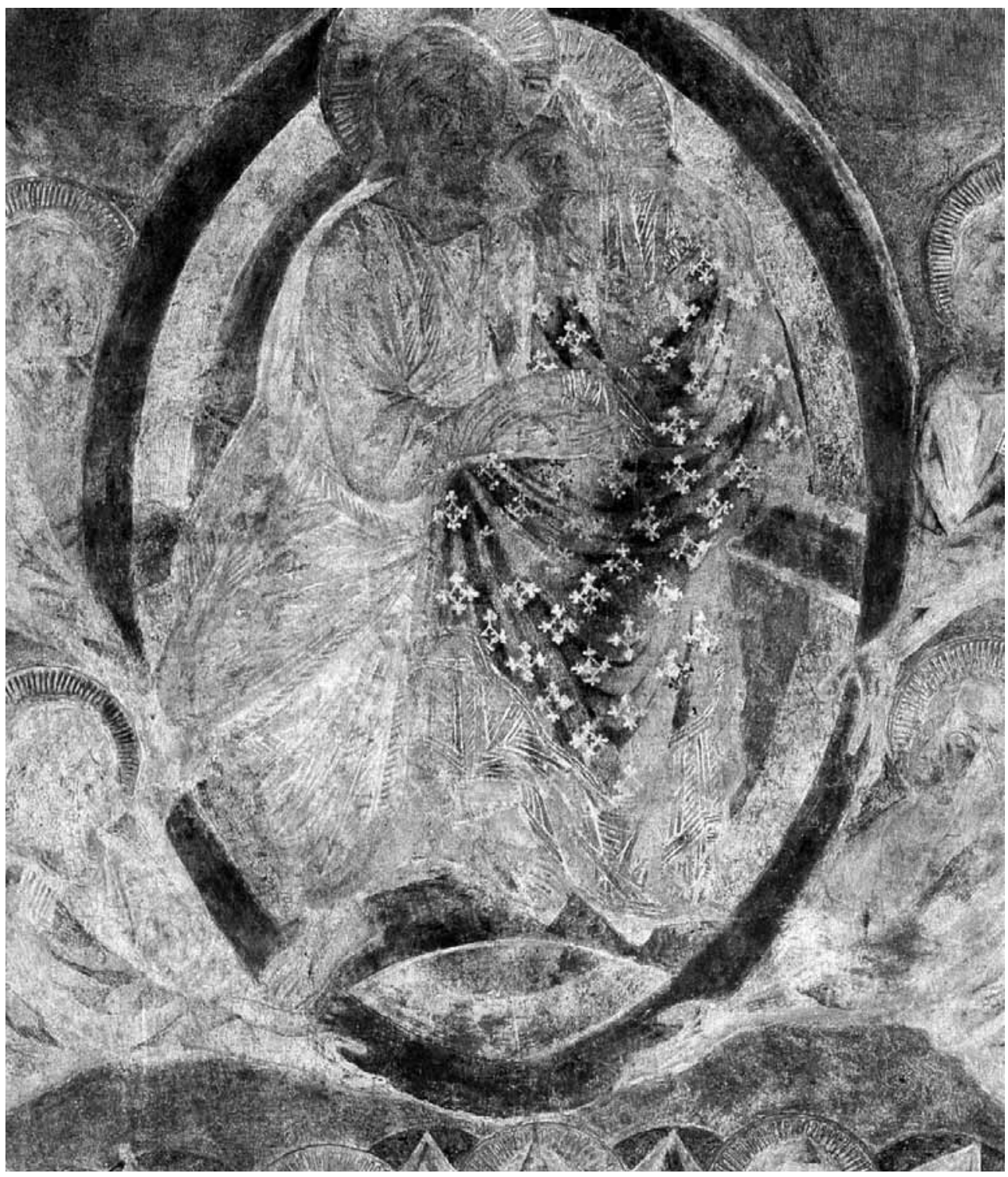

FIg. 1 - Cimabue. Assumption of the Virgin, detail. Assisi, San Francesco, fresco.

The Assumption Feast (August 15) was important in both the Eastern and Western Churches for centuries, and after about 1160 the episode itself was often represented north of the Alps in illuminated manuscripts and later in sculpture. ${ }^{3}$ In Italy, however, Assumption representations were rare; in fact, only two or three, all small in scale, predate Cimabue's monumental image. ${ }^{4}$ There can be no 
doubt that the reason for the subject's appearance at Assisi was the Franciscan position on the issue of dogma. The Franciscan belief ipso facto in Mary's bodily assumption is taken up by Bonaventure who speaks in his sermons directly to this point. Mary's importance, he says, was defined by the honors Christ afforded her at her death. These honors identify her with virtues parallel to those of St. Francis, and underscored her role as chief advocate of St. Francis and the order he founded. ${ }^{5}$ Belief in her assumption in the flesh thereby gains importance as a link in the chain of intercession, from the common people, to whom the Friars Minor preached, to the real Mary who speaks for them directly to her Son.

The lower part of the Assumption composition is an early representation of the open sarcophagus strewn with flowers, and the apostles accompanied by the hosts of heaven who had descended with Christ are also particular to this scene. But what is exceptional is the form given to Mary's rising from the tomb. As is well known, Cimabue's frescoes are in a very bad state of preservation, most probably owning to the artist's excess of creativity. In an attempt to magnify the brilliance of his colors and highlights, Cimabue added lead white to his pigments. Quite soon after completion, the lead began to oxidize and turn black, resulting in the exact opposite of the effect he desired. Today the paintings look more like photographic negatives than brightly colored frescoes, and in many spots the surface is lost altogether. However, what remains visible is truly astonishing: As opposed to almost every depiction of the Assumption, whether before or after this date, Mary is not alone. Enveloped in a banded mandorla carried aloft by four angels, she is accompanied by the figure of the adult Christ. We can make out only the general outlines: the two figures are seated side by side, Mary to the left of Christ. His body fills the vertical dimension of the mandorla; his crossed nimbus breaks through the upper frame and his feet rest of the lower bow. We see the pattern on Mary's outer garment and striations on her robe, and that is about all. But even with this dim view, it is obvious that the almost life-size couple is engaged in an embrace so intimate that their limbs are entangled and the outlines of their bodies seem to merge.

It is only through a series of historical events that we can reconstruct more accurately the action of the figures. In the 1950s Millard Meiss discovered and published a spectacular but at the time disfigured altarpiece, the main panel of which he associated directly with Cimabue's image (Fig. 2). ${ }^{6}$ Attributed to the Maestro di Cesi, and dated about 25 years later than its model, until the mid 19th century the altarpiece was in the cloistered Augustinian convent of Santa Maria della Stella in Spoleto. ${ }^{7}$ It now belongs to the Louvre, exhibited in St. Jean Cap Ferrat, in southern France, reassembled, cleaned and beautifully restored. ${ }^{8}$ In the main panel we see clearly that Christ has his left arm around Mary's shoulder and holds her tenderly with his right. This gesture unmistakably refers

5. Belting 1977, 5-62.

6. Meiss 1962, 75-111.
7. Fratellini 1996, 271-78.

8. Laclotte 1990, 51-52. 


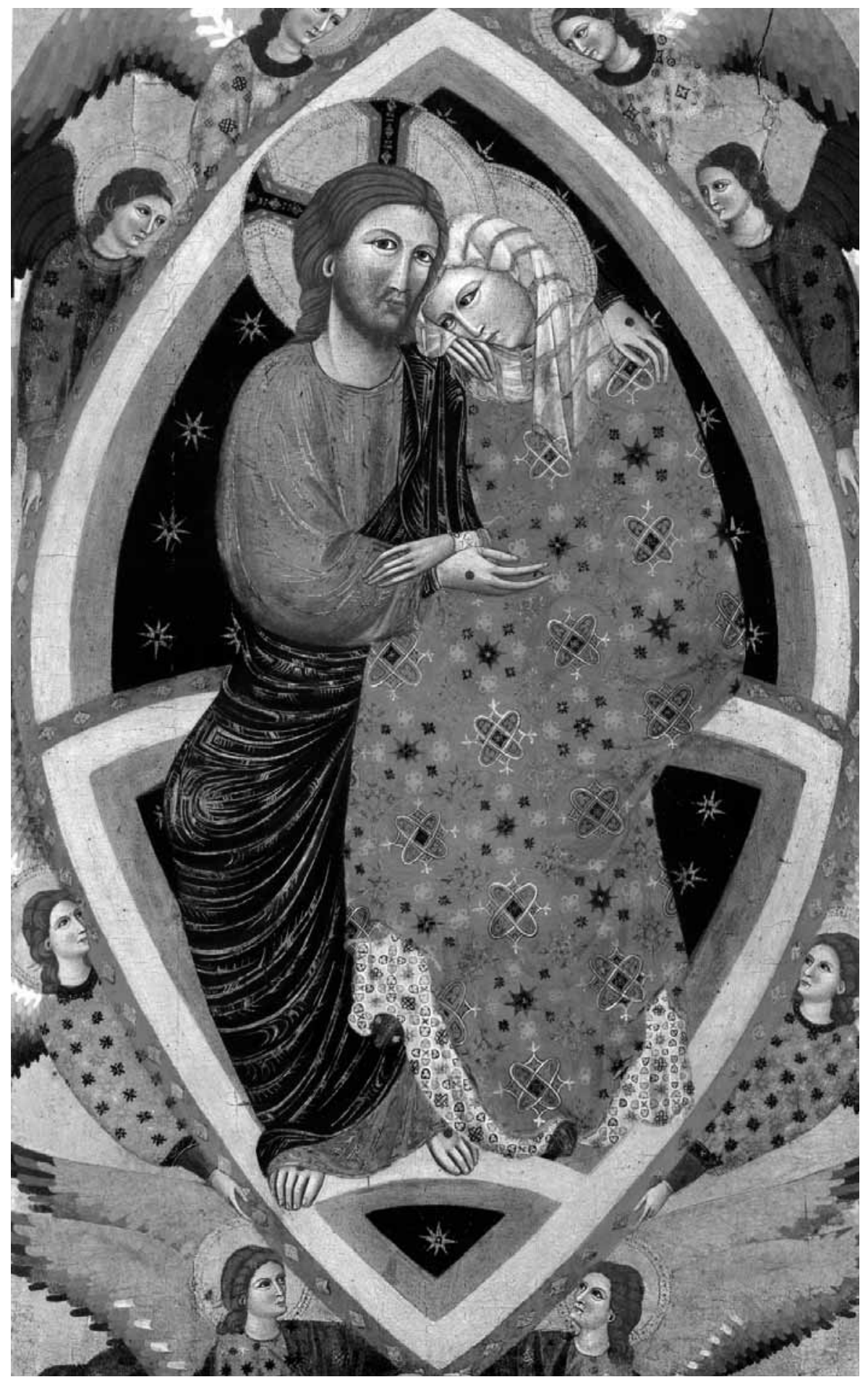

Fig. 2 - Maestro di Cesi. Assumption of the Virgin, detail, the Stella Altarpiece, St. Jean Cap Ferrat, Museo Ephrussi de Rothschild (Musée du Louvre). 
to a beautiful line from the Song of Songs used since the ninth century in the liturgy of the Feast of the Assumption: "leva eius sub capite meo et dextera illius amplexabitur me" [His left hand is under my head and his right hand doth embrace me]. At the same time, Mary's response, bending forward toward Christ, her forehead touching his cheek, reflects the next line from the same poem: "Who is this that cometh up from the wilderness, leaning upon her beloved." [Cant. 2,6; 8,3; 8,5]

Seeing the impassioned gestures in the upper portions of the bodies might already come as something of a surprise to any worshipper. But as the eye moves down the lovers' bodies, credulity will be even further stretched. Both of Christ's bare feet are visible, resting on the mandorla's lower bow. Mary positions the toe of one shod foot on the same support; her other foot hangs free above the hem Christ's mantle. In looking for the anatomical position of this foot we discover that the Virgin has placed her leg over the leg of her Son in an action commonly understood as symbolic of sexual intercourse...not exactly the first action one expects to find in this context. ${ }^{9}$ But the point is that seeing clearly the motifs in the Cesi Master altarpiece enables us to find all the same details in Cimabue's fresco.

Although in modern times the intimacy of the embrace has often been described, the particular leg gestures have not previously been observed. I propose that this oversight is due to a famous early nineteenth-century copy of the fresco from which the suggestive motifs were consciously expurgated. For his great publication on the history of Italian art (1825-1829), Seroux D'Agincourt commissioned a young Englishman, William Ottley, to make copies of the Cimabue frescoes personally guaranteeing them as faithful renderings (Fig. 3). In spite of these assurances, however, it seems that Mr. Ottley fastidiously omitted both Christ's embracing left arm and the even more telltale lower portion of Mary's left leg and foot. ${ }^{10}$ Her drapery quite irrationally comes to an abrupt horizontal edge at the knee. This expurgated version, the most famous replica of the fresco for more than 100 years, in fact, provides further evidence of the sexual nature of the image.

In asking what this motif has to do with Maria-Ecclesia and what is it doing in the heart of one of the most venerable churches of Christendom, we soon discover that the key is the reference to the Song of Songs, the biblical Epithalamium, or nuptial song in honor of the bride and bridegroom at a public wedding. This great poem, which describes the ardent terms in which a young man and woman express their breathless, impatient desire for the consummation of their passion, was considered so powerful and noble, it was presumed to have been of royal origin, and attributed to King Solomon himself. At the same time, its imagery was so graphic that, almost from the beginning, Rabbinical scholars cast the carnal desire in the poem as a divinely inspired allegory of Yahweh's 

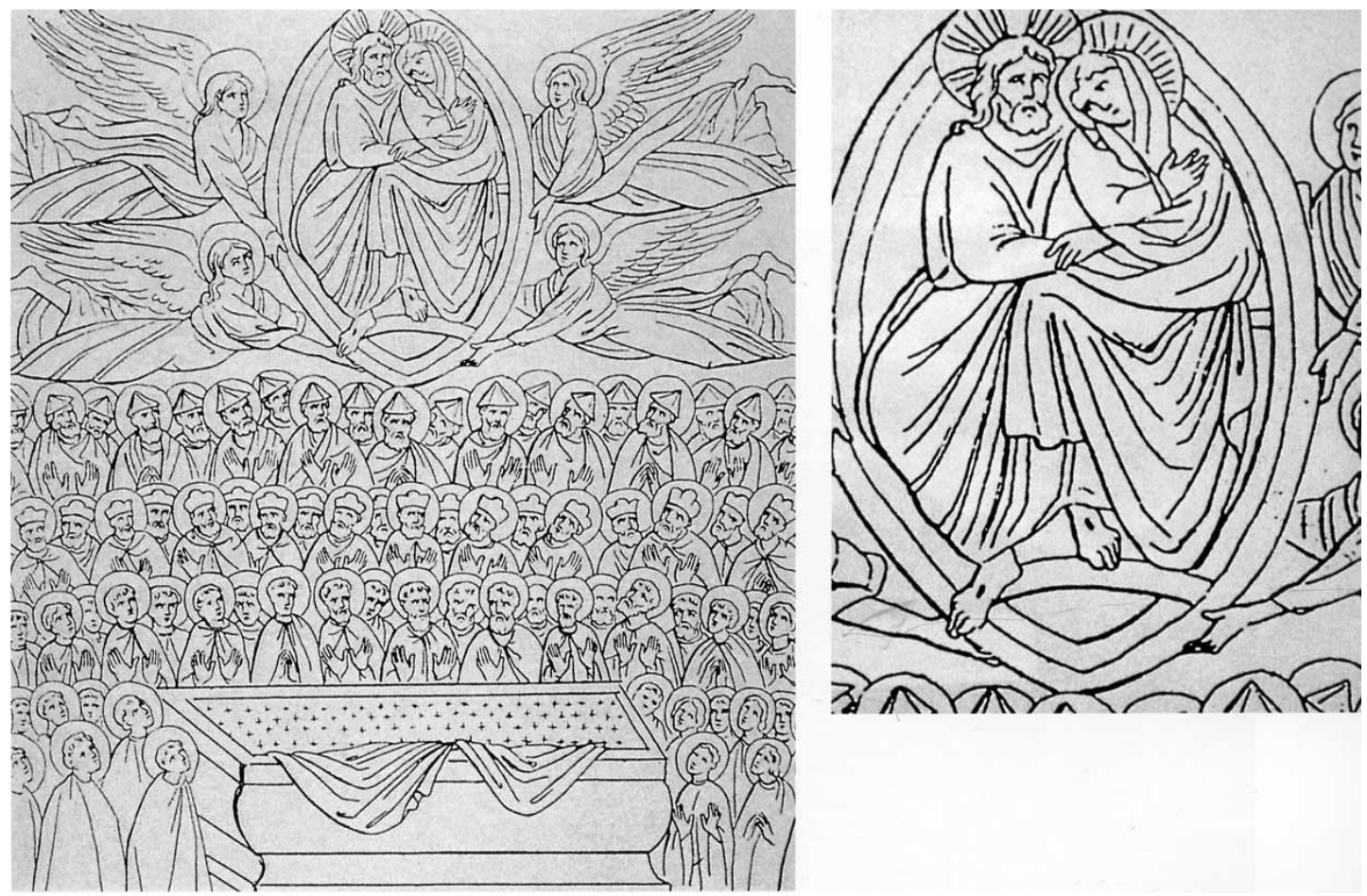

FIG. 3 - William Ottley, Assumption of the Virgin, engraved drawing. About 1816-1818. Copy of Cimabue, (after Seroux D’Agincourt).

love for his Chosen People. ${ }^{11}$ In the Christian era, the love allegory played a crucial role with Christ, as established by the Pauline Letter to the Ephesians, identified as the Sponsus or bridegroom of the Church in the "Royal Wedding," proclaiming the Song of Songs and its mystic marriage as the theme that fulfills the Old Dispensation in the New. ${ }^{12}$

In the visual manifestations of the divine affection, the recipient was conceived as a corporate body identified by the feminine noun "ecclesia" (assembly), personified as this stalwart female, Mater Ecclesia, who becomes the Sponsa herself, joined in marital possession with Christ (Fig. 4).

The Canticle gained great prominence in the first half of the twelfth century when a veritable flood of commentaries issued forth from the monasteries of France and Germany. Exquisite exegesises were written by, among many other churchmen, Rupert of Deutz, Honorius of Autun, Hugh of St. Victor, and above all by the Cistercian St. Bernard of Clairvaux. The truly astonishing aspect of these writings was the heightened eroticism of their language, which openly paralleled spiritual adoration with sexual love making. Honorius of Autun, for example, in 


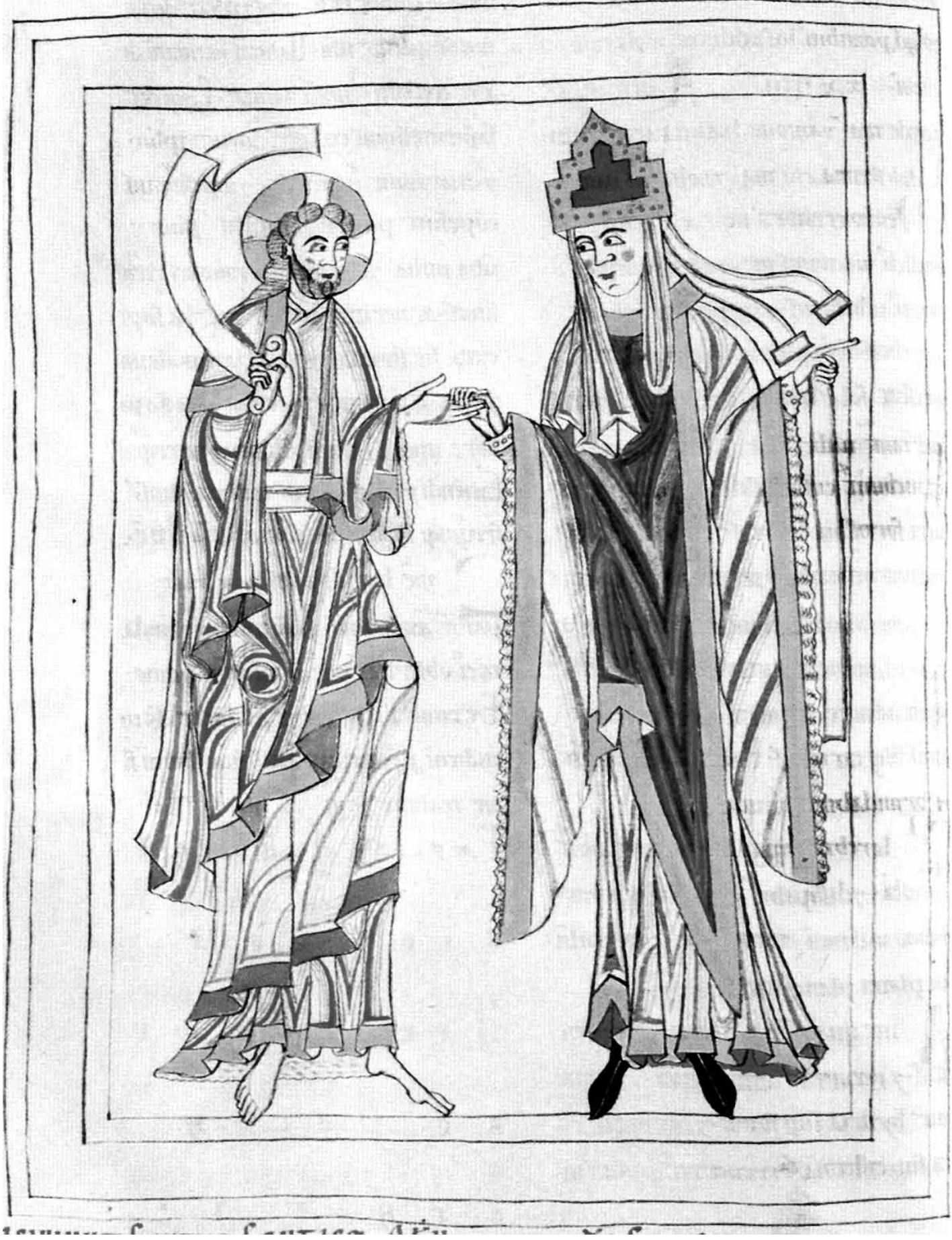

Fig. 4 - Christ and Ecclesia. Manuscript Illumination. Bible. Engelberg, Stifsbibl, Cod. 4, Bd. 2, Frowin Bible, fol.69vo. 1143-1178. [Photo: Library]. 
describing the Song's power to convey the whole of Salvation's history, says it culminates in the supra-temporal Wedding Feast, related..."to five stages of sexual love: 1) Seeing the Beloved (God's covenant with Abraham), 2) Speaking with her (God's conversations through Moses and the Prophets), 3) Touching her (Christ's Incarnation) 4) Kissing her (the gift of Peace given the disciples by the Risen Christ), and 5) having intercourse with her (perfect union enjoyed in heaven)."13

Manuscripts of these commentaries, as well as biblical texts, besides being accompanied by illustrations showing Christ as the Infant in his mother's arms (Fig. 5) just as frequently show the couple as adults (Fig. 6). In each case they are surrounded by what appears to be a circular frame, but which, in fact, is the initial letter of the first word of the first line of the Canticle: "osculetur me osculo oris sui.." (Let him kiss me with the kisses of his mouth: for thy breasts are better than wine. Cant. 1,1) This early example portrays King Solomon himself embracing his beloved, the Daughter of Pharaoh. As he touches her bare breast, she responds with a look of adoration. Soon (Fig. 7) the figures of the bride and bridegroom in the circular frame are Christianized with halos, still seated together, kissing and holding each other with passion. In mid twelfthcentury example illuminating St. Jerome's Commentary on the Song (Fig. 8), they share a halo, now clearly marked with the Christological X. Moreover, perhaps, although it is difficult to judge, in this case, Christ places his leg over the leg of Mary his bride. These small scale, virtually hidden illuminations, are new manifestations of the traditional marriage theme, and it is significant that they developed just as the churchmen were creating the first comprehensive interpretations of the Canticle in which the abstract notion of Ecclesia was wedded to the human sponsa of the Canticle and identified as the Virgin Mary. In these monastic commentaries, in fact, the Old Testament love poem was established as the primary vehicle for Catholic Marian ideology and devotion. ${ }^{14}$

The first monumental public version of the motif of Mary and the adult Christ seated amorously together is the stupendous mosaic in the apse of Santa Maria in Trastevere, the official commission of Pope Innocent II about 1140-43 (Fig. 9). ${ }^{15}$ This great monument was part of the same extraordinary surge of interest in the emotional symbolism of the Song of Songs just mentioned. Here, a hypnotically powerful figure of Christ makes a bold gesture, astonishing in its own time, by placing his arm around Mary's shoulder in the same warm embrace as the line in the Song "Laeva eius sub capite meo...et dex(t)era illius amplexabit(ur) me". While the gesture had a prior history in Rome ${ }^{16}$ in Trastevere it is identified directly with the Canticle since the whole verse is actually inscribed in gold on blue on the Old Testament scroll Mary holds. Remarkable too is the direct reference to the Assumption, since Christ holds a copy of the Divine Office in the more

13. Astell 1990, 31-33; (P.L.172: cols. 350-51). See also Matter 1990 passim.

14. Fulton 1994.
15. Kitzinger 1980, :6-19; Nilgen 1981, 1-33.

16. E.g. the apse mosaic in Santa Prassede in Rome. 


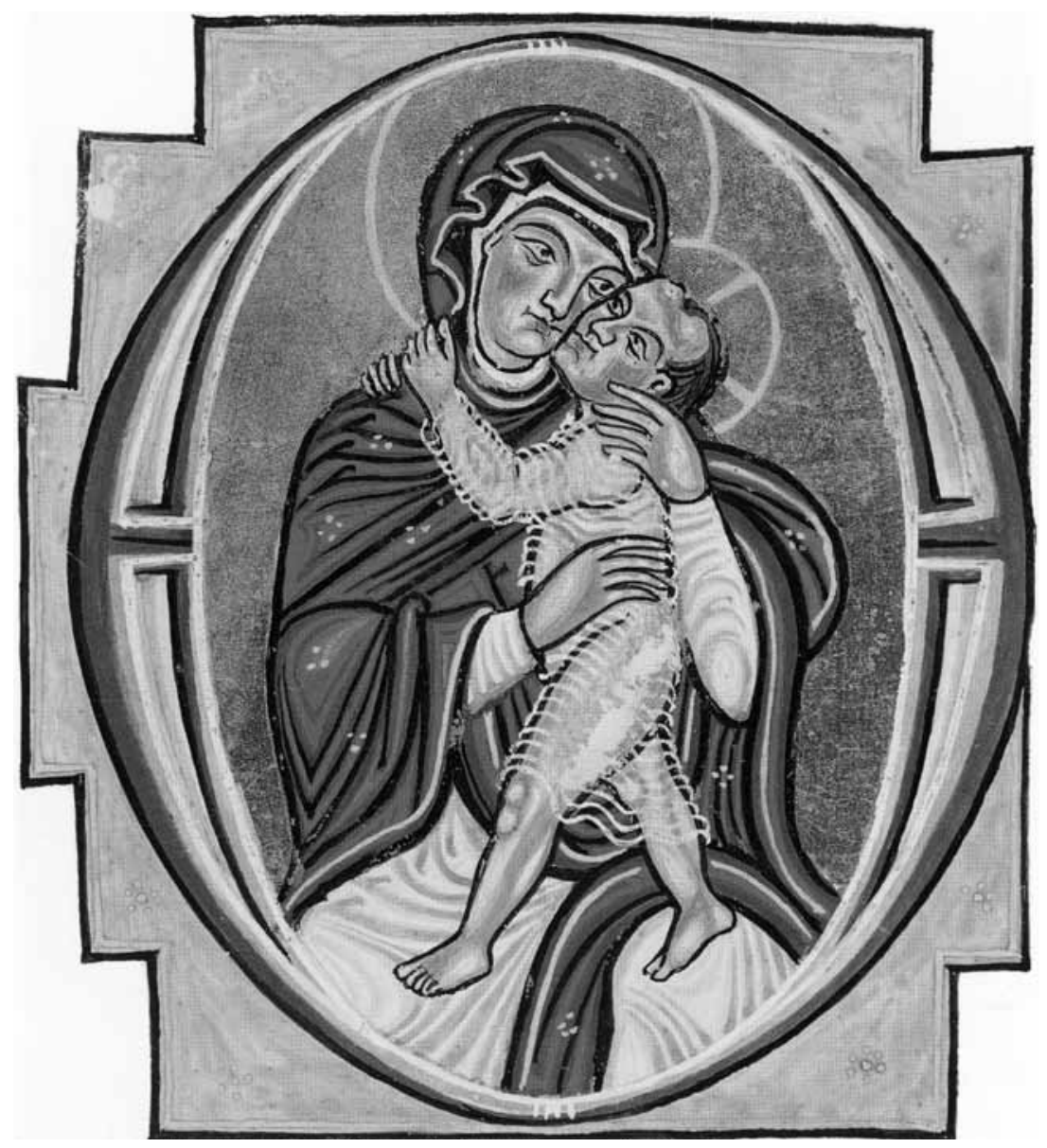

FIg. 5 - Mary and the Striding Christ Child. Manuscript Illumination. Bible. Lyons, Bibliothèque de la Ville, MS. 410-411, Bible I, fol. 207v. 1150-1200 (Photo [Index]).

modern codex form, inscribed in black on white with an antiphon written specifically for that feast: "Veni electa mea et ponam in te thronum meum" (Come, my chosen one, I will put my throne in you). The antiphon, known since the ninth century, ${ }^{17}$ has its share of connubial allusion which was underscored by two contemporary commentators. St. Bernard, in his twenty-seventh sermon on the Song of Songs, says: "No need to be surprised that the Lord Jesus should be pleased to dwell in this heaven, which he not only called into being by his word like the other creatures, but fought to acquire and died to redeem. And when his passion was over the longing of his heart found echo in the words: 'This is my resting-place for ever; here I will dwell, for I have desired it' (Ps. 131, 14). Happy

17. Corpus Antiphonalium Officii. 4 vols. Ed. by R.-J. Hesbert. Rome, 1963-75, 4:448. 


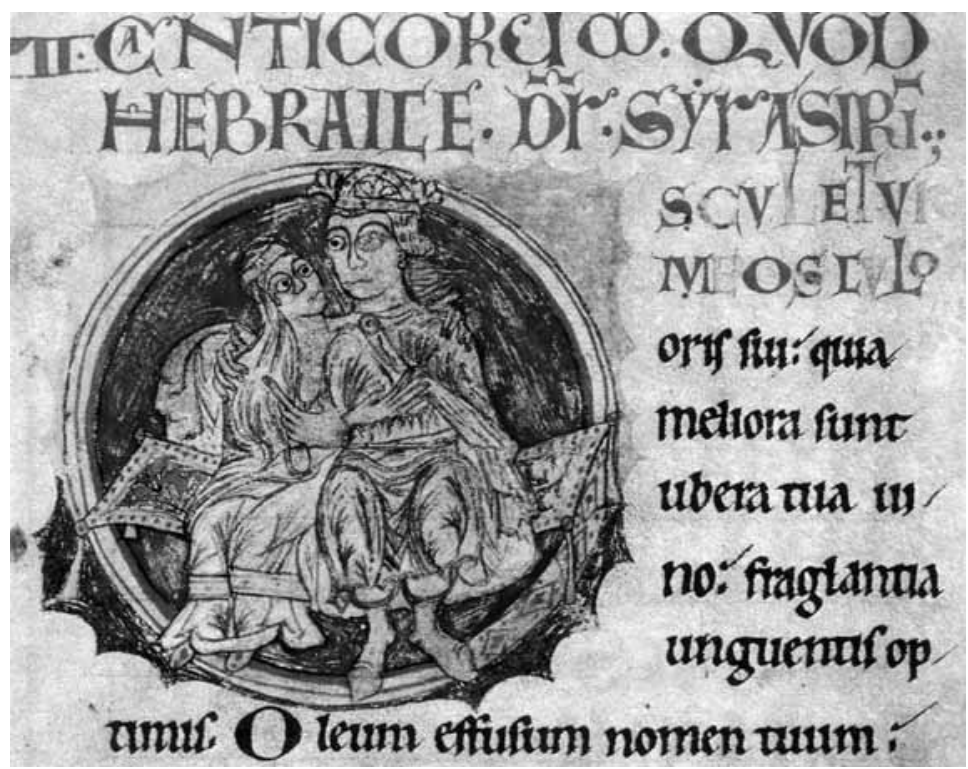

Fig. 6 - King Solomon and Beloved. Manuscript Illumination. Bible. Reims, Bibliothèque Municipale. MS 18, fol. 149r. 1090-1120 [Photo: Library].

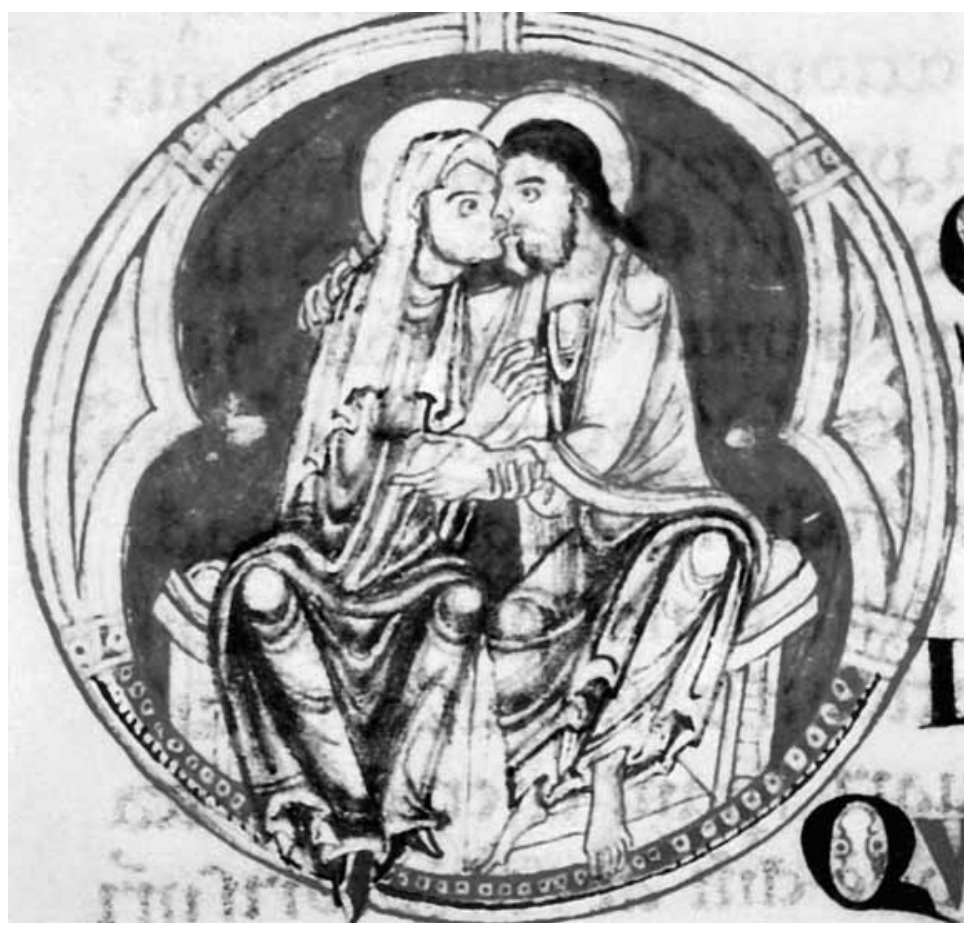

Fig. 7 - Sponsus and Sponsa (Kissing Couple, seated). Manuscript Illumination, attr. the Alex Master. Bede, Commentary on the Song of Songs. Cambridge (Eng.). King's College, MS 19, fol. 21vo. 1123 [Photo: Library]. 


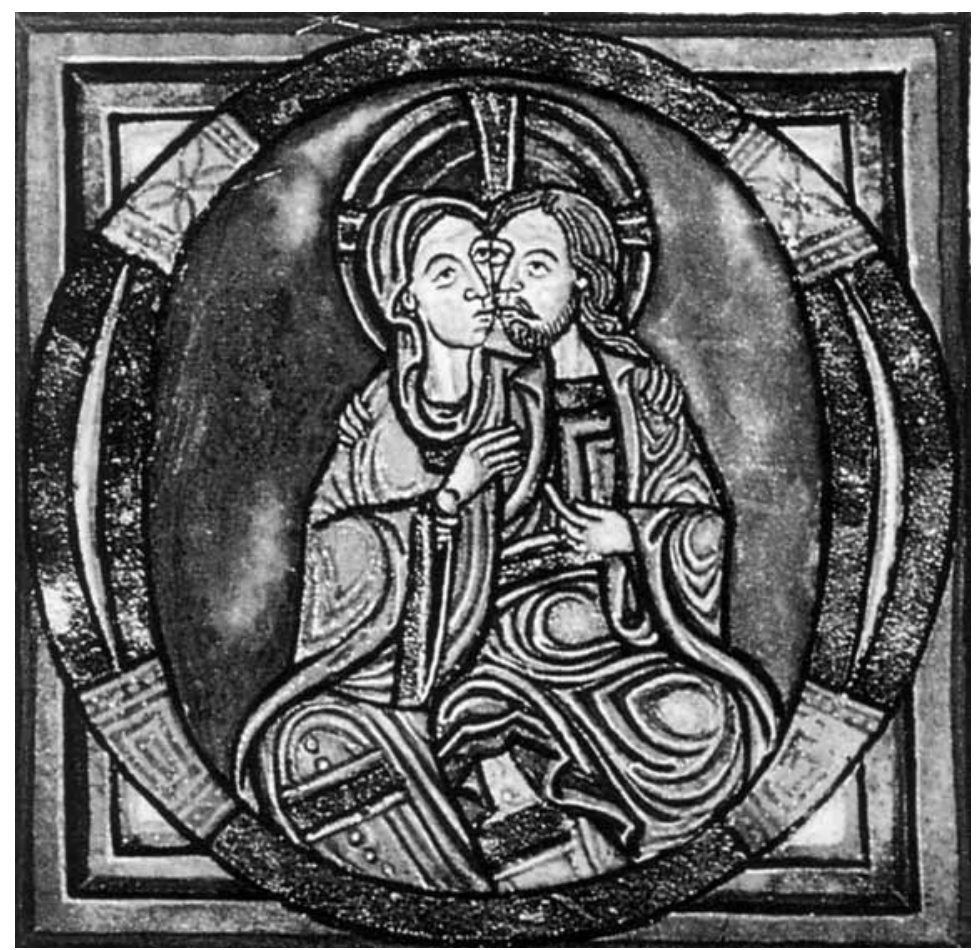

Fig. 8 - Christ and Mary/Sponsa. Manuscript Illumination. St. Jerome, Expositio in Canticum Canticorum. Paris, Bibl.Nat. MS.lat. 1808, fol. 1vo. ca. 1150.

therefore is the one to whom he says: 'Come my chosen one, and I shall set up my throne within you'." 18 It has not been pointed out before that the two previous lines of Psalm 131 are the probable source of this remarkable antiphon: "The Lord hath sworn in truth unto David; he will not turn from it; Of the fruit of thy body will I set upon thy throne. If thy children will keep my covenant and my testimony that I shall teach them, their children shall also sit upon thy throne for evermore.(Ps. 131, 11-12).

The analysis of Bernard's fellow Cistercian, Abbot Guerricus is the most explicit. In two sermons he has Christ extend the dialogue with Mary, telling her: "You yourself will be my throne, you will contain in you the king's majesty...you will be the nuptial bed of the bridegroom made flesh, you will be the throne of the crowned King." ${ }^{19}$ Thus with exquisite ambiguity, Guerricus has Christ refer to his own prenatal dwelling as the nuptial bed of his own marriage. The Trastevere image was surely the progenitor of many of the more explicit, and less public, small manuscript examples we have just seen.

18. Bernard of Clairvaux 1971-80, 3:82, Sermon 27.9, "De ornatu sponsae et qualiter anima santa in coelum dicatur. "; this observation is
Kitzinger's, 1980, 11.

19. Guerric d'Igny 1973, 428-41. 


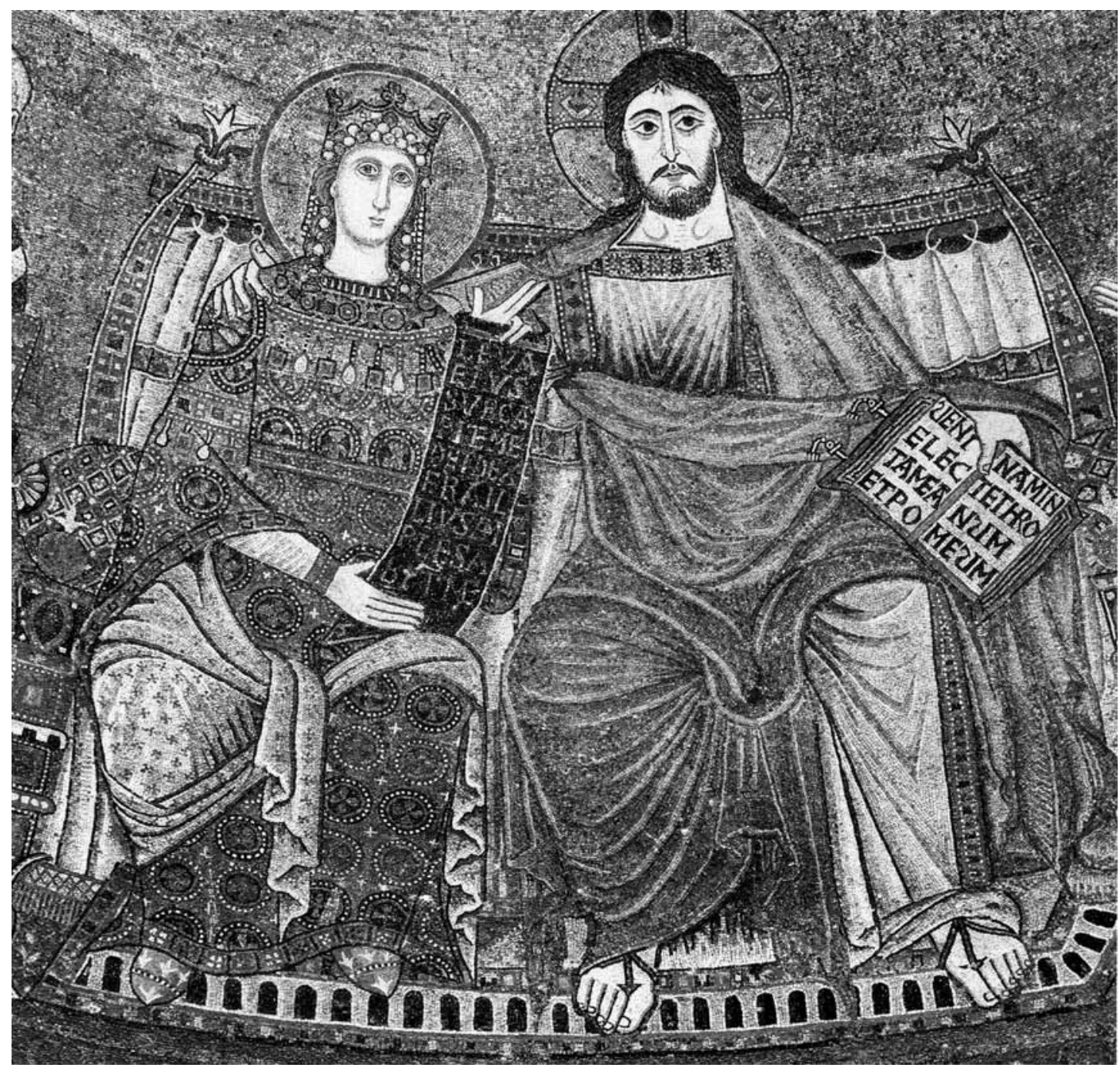

Fig. 9 - Christ and Mary in Glory. Mosaic. Rome. Santa Maria in Trastevere, apse. 1240-1243) (Anderson 1932).

A hundred and fifty years later Cimabue's version of the Mystic Marriage incorporates many of the motifs from this tradition. But at the same time his life-size image is more overtly sexual than anything that came before. Now we may ask what, precisely, was the meaning of marriage in the forth quarter of the 13 th century that could have produced the position the fresco takes?

Strange to say I will begin this part of the discussion with Session 24, Canon I, of the Council of Trent (11 November 1563), where there appears the following statement: "If any one shall say that matrimony is not truly and properly one of the Seven Sacraments of the Evangelical Law, instituted by Christ our Lord, but was invented in the Church by men, and does not confer grace, let him be 
anathema." ${ }^{20}$ The force of the statement depends on the claims to which it is a response, namely the accusations of Luther and Calvin. The former declared "No one indeed can deny that marriage is an external worldly thing, like clothes and food, house and home, subject to worldly authority....marriage may therefore be a figure of Christ and the Church; it is, however, no Divinely instituted sacrament, but the invention of men in the Church, arising from ignorance of the subject." ${ }^{11}$ Calvin's statement was even stronger: “...matrimony, which all admit was instituted by God, though no one before the time of Gregory regarded it as a sacrament. What man in his sober senses could so regard it? God's ordinance is good and holy; so also are agriculture, architecture, shoemaking, hair-cutting all legitimate ordinances of God, but they are not sacraments". ${ }^{22}$

All this Sturm und Drang indicates disagreement, or at least centuries long discussions as to the sacramentality of matrimony. The fundamental starting point is course the passage in the Pauline Letter to Ephesians we have already mentioned as the source for the concept of Christus Sponsus. But the letter continues to develop the idea:

"Wives, submit yourselves unto your own husbands, as unto the Lord. For the husband is the head of the wife, even as Christ is the head of the church: and he is the savior of the body. Therefore as the church is subject unto Christ, so let the wives be to their own husbands in every thing. Husbands, love your wives, even as Christ also loved the church, and gave himself for it that he might sanctify and cleanse it with the washing of water by the word, That he might present it to himself a glorious church, not having spot, or wrinkle, or any such thing; but that it should be holy and without blemish [reference later applied to Mary]...For this cause shall a man leave his father and mother, and shall be joined unto his wife, and they two shall be one flesh. This is a great mystery: but I speak concerning Christ and the church." [in the Vulgate the word used is sacramentum].

As Calvin observed, Gregory was indeed the first to introduce the notion that marriage is a Sacrament of the New Law, meaning that it ranked with baptism, the Eucharist, confirmation and Holy Orders in conferring interior Divine grace and religious consecration of the recipient. He was soon followed by Augustine who made it explicit that the one function of marriage was procreation. Later theologians were more skittish about the religious significance of the institution, and open controversy began around the end of the eleventh century, when it was objected that marriage, along with penance, was different from true sacraments in that they involved external ceremonies and even in the immediate purpose of the production of grace. Marriage, it was said, is in the nature of a contract, and penance is in the nature of a judicial process. When the Waldesians, along with

20. Canons and Decrees 1978, 180-82: Session 24, Canon 1.

21. Luther 1947, 208-24.

22. McNeill 1977, 2:1480-82, 9 (IV, xix, 34). 
the Albigensians openly condemned Marriage as a sacrament, and particularly the Cathars condemned all kinds of carnal activity, the Church began to speak explicitly of the sacramentality of marriage, recommending public consent given in the presence of a priest and witnesses, as well as ecclesiastical marriage ceremonies. Finally Innocent III in his Profession of Faith of 1208, included marriage as a sacrament. ${ }^{23}$ Shortly thereafter the first representations of marriage and virtuous marital intercourse, as a religious as well as a moral virtue, began to appear.

We find an example in an Austrian model book, probably made at the Cistercian abbey of Rein (Salzburg) that has been dated 1208 or a bit later (Fig. 10). ${ }^{24}$ The first in a series of twelve small scenes of human activities, the pen and ink drawing on vellum shows a completely clothed man and woman seated together, embracing and fondling each other with devotion. Touching his wife's chin in decorous familiarity, the husband crosses his right leg over his wife's left thigh, thus alluding to the sexual act. The point of their union is the offspring who accompany them, an adolescent who gestures toward the parents while raising the head of a babe in a crib. The composition is thus an emblem of the relationship between physical intimacy and procreation in legitimate marriage. As the function of this drawing, along with the others in the series was as a model for other artists to follow, the motif of intertwined legs as a symbol of licit love, by the early thirteenth century, was becoming a received convention.

By the time Cimabue transferred the figural symbol for virtuous physical love to Christ and Mary in his monumental scene, some seventy years later, the meaning of the image was common knowledge.

The intense passion of Cimabue's image is related, moreover, to the fact that human sexuality as a metaphor for divine love played a major role in the theology of the Franciscans. In fact, St. Francis himself couched his own dedication to the virtue of poverty in terms of marital love in the allegorical tract called "St. Francis's Holy Intercourse (sacrum commercium) with Lady Poverty". ${ }^{25}$ The classic illustration of this concept is the fresco representing the Wedding of Francis and Poverty, perhaps by the Maestro delle Vele, in one of the webs of the groin vault of the crossing of the Lower Church of San Francesco at Assisi. As Francis places a ring on Poverty's finger Christ acts as a priest and witness to the ceremony.

Bonaventure, too, was effusive in his development of the theme of love, particularly as verification of the doctrine of the Assumption in the flesh. A matter of considerable debate at this time, in his sermons, Bonaventure argues that Mary as the bride of Christ was taken up as an integral whole, and transferred to the heavenly bedchamber of the King. In his commentary on the Canticle, he describes Christ's passion in love as so rapturous that the soul

23. Maccarrone 1940, "De quadripartita specie nuptiarum."
24. Scheller 1995, 149-54.

25. Brufani 1990. 


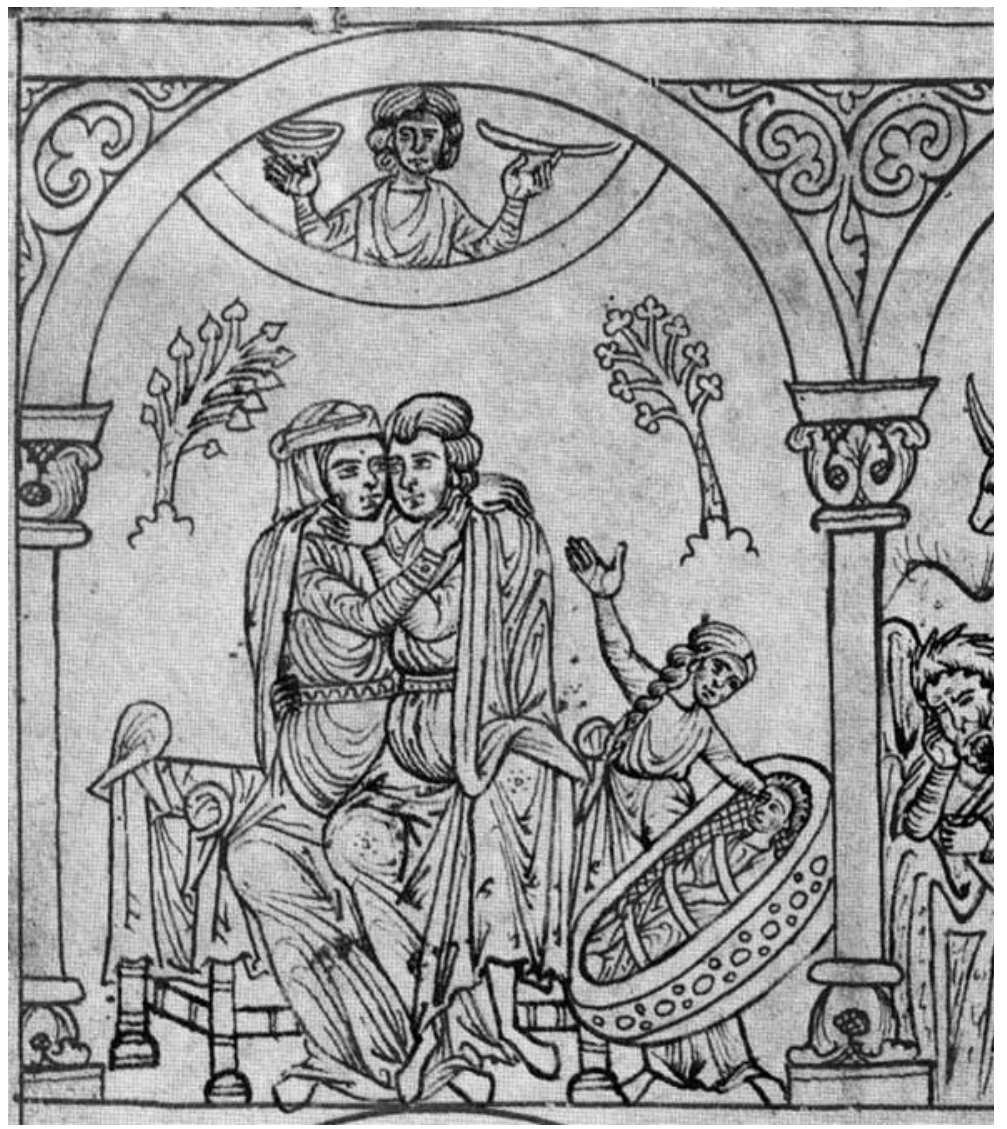

Fig. 10 - Emblem of Marriage, ink on vellum, Model Book, Cod. 507, fol. 1v.. detail. Vienna, Nationalbibliothek. 1208/13 (Photo: Library).

dissolves in his amorous embrace. He defines the bond between mother and son, between husband and bride, between God and the worshipper, as infinitely sweet and infinitely desirable. And then, so that he is not misunderstood, he immediately reminds the worshipper that in this exercise one must root out love of creatures and turn one's heart toward the Spouse himself. The gift of redemption will come (as Bonaventure promises) to all worshippers when they too have been "married to Christ with chaste love." 26

One other element in the theology of marriage makes the gestures of Cimabue's figure an imperative. In the Roman catholic culture of the Middle Ages, a marriage was legal and binding on the basis of consent between the spouses and their guardians. In the traditions of the north, on the other hand, in Frankish and Germanic traditions, a marriage was not considered binding until consum-

26. Bonaventure 1960-66, 1:77-86. 
mated by sexual intercourse. By the last quarter of the thirteenth century these two traditions had blended to the point that St. Thomas Aquinas made the following statements of doctrine:

"Before marital intercourse there is only a spiritual bond between husband and wife, but afterwards there is a carnal bond between them...(only) after consummation it signifies the union of Christ with the Church....Before consummation the body of one consort is not absolutely delivered into the power of the other, but conditionally...But by marital intercourse the aforesaid delivery is completed, because then each of them enters into bodily possession of the power transferred to him." 27

Thus was the way not only prepared for Cimabue's image of a loving couple graciously ascending to heaven, the pose of consummation, in which Mary takes Christ into her womb, was, in effect, required to complete the ancient marital figure and carry it to a new level of reality. Through his emotionally charged configuration Cimabue intermingles human sexuality with the divine gifts of spiritual love. The enhanced corporeality of his style makes it manifestly visible that Christ came to earth to fetch Mary; that she was assumed in the body, and that she was joined to her spouse in heavenly matrimony forever. Cimabue's intensified verisimilitude shows carnal love as proof of spiritual miracles.

Marilyn Aronberg Lavin

56 Maxwell Lane

Princeton, NJ 08540 USA

27. Aquinas 1868, 5:(694-96), 153, 2, “De vitio luxuriae". 


\section{BIBLIOGRAPHY}

Aquinas, St. Thomas. Summa Theologica, 9 vols. Paris, L. Vivès, 1868.

Astell, A. W. 1990: The Song of Songs in the Middle Age. Ithaca and London.

Augustine, St. De bono coniugali. In Sancti Aureli Augustini Opera. Corpus Scriptorum Ecclesiasticorum Latinorum 41, ed. J. Zycha. Vienna, 1900; De nuptiis et concupiscentia. In Sancti Aureli Augustini Opera. Corpus Scriptorum Ecclesiasticorum Latinorum, ed. C. F. Urba and J. Zycha. Vienna, 1902; Sermons for Christmas and Epiphany. Trans. T.C. Lawler. Ancient Christian Writers 15. Westminster, Md., (1952); Saint Augustine: Treatises on Marriage and Other Subjects. Fathers of the Church 27, ed. R. J. Deferrari. New York, 1955; On the Holy Trinity (De Trinitate). vol. 3 (1956) in Works of St. Augustine. A Select Library of the Nicene and Post-Nicene Fathers of the Christian Church, ed. P. Schaff et al. Grand Rapids, Mich., 1983-86.

Belting, H. 1977: Die Oberkirche von San Francesco in Assisi. Berlin.

Bernard of Clairvaux. The Works of Bernard of Clairvaux. 5 vols. Spencer, Mass. and Kalamazoo, Mich., 1971-80.

Brufani, S Sacrum commercium sancti Francisci cum domina Paupertate. Santa Maria delle Angeli, 1990.

Bonaventure, "Journey of the Mind of God" The Works of St. Bonaventure, 4 vols. trans. J. de Vinick . Patterson, NJ, 1960-1966.

Canons and Decrees of the Council of Trent, trans. H. J. Schroeder. Rockford, IL, Tan Books, 1978.

Corpus Antiphonalium Officii. 4 vols. Ed. by R.-J. Hesbert. Rome, 1963-75.

Feliks, Y. Song of Songs; Nature, Epic and Allegory. Jerusalem, 1983.

Fratellini, B. M. "Giuseppe Sordini e le vicende del Dossale di Cap-Ferrat e delle Croci dipinte." In Scritti di Archeologia e Storia dell'Arte in onore di Carlo Pietrangeli, ed. V. Casale, F. Coarelli, and B. Toscano, 271-78. Rome, 1996.

Fulton, R. L. "The Virgin Mary and the Song of Songs in the High Middle Ages." Ph.D. diss., Columbia University, 1994.

Guerric d'Igny. Sermons. Sources Chrétiennes (Latin and French). Vols. 166, 202. Ed. J. Morson and H. Costello. Trans. P. Deseille. Paris, 1973.

Innocent VIII. "De quadripartita specie nuptiarum" (P. L., CCXVII, 923-968).
Kitzinger, E. “A Virgin's Face, Antiquarianism in TwelfthCentury Art.” Art Bulletin 62 (1980):6-19.

Laclotte, M. Polyptyques. Paris, 1990.

Lavin, M. A. Place of Narrative: Mural Decoration in Italian Churches, 431-1600 A.D. (Chicago, 2d ed. 1994).

Lavin, M. A. and I. Lavin. Liturgia d'Amore: Immagini del Cantico dei Cantici nell'arte di Cimabue, Michelangelo, and Rembrandt. Modena (Panini), 1999, and The Liturgy of Love: Images from the Song of Songs in the Art of Cimabue, Michelangelo, and Rembrandt. Lawrence, KA., 2001.

Luther, Martin. Three Treatises: An Open Letter to the Christian Nobility of the German Nation Concerning the Reform of the Christian Estate. A Prelude on the Babylonia Captivity of the Church. A Treatise on Christian Liberty. Ed. and trans. C. M Jacobs, A.T.W. Steinhaeuser and W.A. Lambert. Philadelphia, Muhlenberg Press, 1947.

Maccarrone, M. Chiesa a stato nella dottrina di papa Innocenzo III. Rome 1940.

Matter, A. E. The Voice of My Beloved: The Song of Songs in Western Medieval Christianity. Philadelphia, 1990.

McNeill, J. T. ed. Calvin, "Institutes of the Christian Religion. trans. F. L. Battles, 2 vols.. Philadelphia, Westminster Press, 1977.

Meiss, M. "Reflections of Assisi: A Tabernacle and the Cesi Master." In Scritti di storia dell'arte in onore di Mario Salmi, 2 vols., ed. L. Venturi, 75-111. Rome, 1962.

Nilgen, U. "Maria Regina-Ein politischer Kultbiltypus?” Römisches Jahrbuch für Kunstgeschichte 19 (1981):1-33.

Scheller, R.W. Exemplum: Model-book Drawing and the Practice of Artistic Transmission in the Middle Ages (ca. 900-ca. 1470). Trans. M. Hoyle. Amsterdam, 1995.

Schiller, G. Ikonographie der christlichen Kunst. 4 vols. Kassel, 1980.

Seroux d'Agincourt, G.B.L.G. Storia dell'Arte, dimostrata coi monumenti dalla sua decadenza nel IV secolo fino al suo Risorgimento nel XVI. 6 vols. Prato, 1826-29

Steinberg, L. "Michelangelo's Florentine Pietà: The Missing Leg." Art Bulletin 50 (1968): 343-353.

Verdier, P. Le Couronnement de la Vierge: Les origines et les premiers dévelopments d'un thème iconographique. Montreal and Paris, 1980.

Wechsler, J. G. Some Aspects of the Illustrations to the Song of Songs in Twelfth and Thirteenth Century Manuscripts. M.A. thesis, Columbia University, 1967. 
